\title{
Columbanus, Bobbio, and the Lombards
}

\author{
STEFANO GASPARRI
}

The impacts of Columbanus and Irish monasticism on the Lombard and Frankish kingdoms differed sharply, to the extent that Bobbio remained the only Columbanian monastery in Italy. This fact is well known, although a definitive explanation has yet to be provided. ${ }^{1}$ One of the chief difficulties in finding such an explanation derives from the sheer scarcity of the Italian sources in the period between the end of the sixth and the beginning of the seventh centuries. Paul the Deacon, who is our main point of reference for the entire history of Lombard Italy from the invasion until the end of the reign of King Liutprand (744), writes, for example, about Arioald (626-635) that "very little about the deeds of this king have reached our notice." Something similar could be said of practically the entire period, with a few exceptions that we discuss below. Immediately after that statement, Paul describes the foundation of Bobbio itself:

It was about this time that the blessed Columbanus, born of the Irish people, came to Italy after he had built a monastery at a place known as Luxeuil in Gaul. He was received joyfully by the king of the Lombards and built the monastery known as Bobbio in the Cottian Alps, which lies 40 miles away from the city of Ticinum. Many possessions were lavished on this place by different princes and other Lombards and here there developed a great congregation of monks. ${ }^{2}$

Besides this passage, Bobbio only appears on one other occasion in the Historia Langobardorum, in Paul's description of the provinces of Italy. The monastery is named as one of the major centers of the fifth province, the Cottian Alps, alongside Acqui, Tortona, Genoa, and Savona. Bobbio is the only nonurban center

1. General studies on Bobbio are Richter 2008 and Polonio 1962.

2. Paul the Deacon, Historia Langobardorum IV.41: 134: Circa haec tempora beatus Columbanus ex Scottorum gente oriundus, postquam in Gallia in loco qui Luxovium dicitur monasterium construxerat, in Italiam veniens, a Langobardorum rege gratanter exceptus est, coenobiumque quod Bobium appellatur in Alpibus Cottiis aedificavit, quod quadraginta milibus ab urbe dividitur Ticinensi. Quo in loco et multae possessiones a singulis principibus sive Langobardis largitae sunt, et magna ibi facta est congregatio monachorum. 


\section{Lombard Italy and Columbanus's Legacy}

listed, in itself an indicator of its fame, which was firmly established by the end of the eighth century. ${ }^{3}$

Reading the text, Bobbio's connection with Pavia is immediately emphasized. This is more than simply a geographical connection; that Paul recorded the foundation of Bobbio immediately after his notice of Arioald's reign suggests that he understood there to be a special relationship between the monastery and the Lombard kings, one that went beyond donations of land. Nevertheless, Paul knew little about Bobbio, so little that he mistakenly associated its foundation with Arioald's reign. In reality Columbanus arrived in Italy in 612 or 613, toward the end of Agilulf's reign, and it was under this sovereign that the foundation of the monastery took place. ${ }^{4}$ The diploma issued by Agilulf in favor of Columbanus has survived, albeit in a ninth-century copy whose authenticity, not least because of the great number of forgeries from Bobbio, has long been in question. Nevertheless, the overall content of the document certainly is authentic. ${ }^{5}$ The diploma, while extensively interpolated, represents the earliest known example issued by a Lombard king. This too is further evidence of the importance of the monastery even at the beginning of its history.

The text of Agilulf's diploma describes the donation of the church of Saint Peter, in the place called Bobbio, "to the venerable man, the blessed Columbanus, and to his companions," so that the monks could settle there and own the land. The diploma establishes the boundaries of the church's possessions, which include half of a well (puteus), the ownership of which had already been conceded by the same king to Sundrarit. We know about Sundrarit from a narrative source, the "Continuator of Prosper," and he appears to have been an important figure at the royal court, so much so that in a subsequent diploma issued by Adaloald he is described as vir magnificus. ${ }^{6}$ Furthermore (and this is of great significance), Agilulf's diploma ends with a prohibition on any royal official going against the judgments of the king expressed in the privilege; this is a powerful prohibition, although very different from the later formulas of immunity found in the Carolingian period. ${ }^{7}$

The contents of the diploma are confirmed by the account of the Vita Columbani, written by Jonas of Bobbio at the request of the abbot Bertulf. Jonas writes that Agilulf, after he had honorably received Columbanus, conceded to

3. Paul the Deacon, Historia Langobardorum II.16: 82.

4. For Polonio 1962: 10, the foundation date is 614 .

5. CDL III.1: 3-7 (Milan, 24/07/613?).

6. For Sundrarit see Prosperi Continuatio Hauniensis: 640; for Adaloald's diploma see below, footnote 9.

7. CDL III.1: 7: dantes quapropter omnibus ducibus, gastaldiis seu actionariis nostris omnimodis in mandatis ut nullus eorum contra hac precepti nostri pagina ire quandoque presumat. 
him the right to settle wherever he wanted to in Italy. Then, on the advice of a certain Iocundus, he identified the church of Saint Peter as the right place, situated "in the solitude of the countryside of the Apennines," where miraculous events had occurred. ${ }^{8}$ The almost complete correspondence between Jonas's account and the content of the diploma, although seeming to confirm the substantial veracity of events, should nevertheless be viewed with caution. Indeed, while it is true that Jonas could have taken the diploma as a model, the opposite could equally have been the case: later copyists of the diploma could have interpolated the original text with references taken from the Vita Columbani.

Agilulf's privileges (possibly repeated later in a lost diploma granted to the second abbot Athala) were confirmed by his son Adaloald a few years later. ${ }^{9}$ In the new diploma, it is written that the king, on Athala's request, issued the document during a visit to Bobbio to see Columbanus's tomb. Adaloald specifies that among the donations made by his father was "wood for cooking salt" (associated explicitly with Sundrarit's well), but the real novelty in this second diploma is to be found in the donation of mountain territory (the "small Alp called Pennice"), which had already been intended for the monastery by the king's mother, Theodelinda. The diploma says that the queen, "out of love for our father Columbanus" (who clearly had not died yet, so this must have been in 613) had climbed up the mountain "in order to see this place," an act that suggested her intention later to donate the land to the monastery. ${ }^{10}$ Some years later, Adaloald again confirmed the donations made by him and his father to the third abbot, Bertulf. On this occasion, we also see recorded and confirmed possessions that were partially donated and partially sold to the monastery by a certain Zusso, probably on a date following the issue of the first diploma. ${ }^{11} \mathrm{By}$ now the original nucleus of the monastery's property was fully formed.

It is possible to define Bobbio as a royal monastery, as did older historiography, which was however strongly dependent on legal categories that are hardly appropriate for describing early medieval societies. ${ }^{12}$ From what has been said so far it should be clear that there was in practice a very strong relationship between Bobbio and the Lombard royal family, represented by Agilulf, Theodelinda, and

8. VC I.3O: 220-1.

9. CDL III.2: 7-12 (Pavia, 25/07/624?); III.3:14-5: per hoc generale nostrum preceptum cedimus vobis ad limen Beati Petri ibidem in Dei nomine licentia habitandi et possidendi, undique fines decernimus, sicut a domno et genitore nostro [. . . ] sancte memorie Columbano vel Atalane [abbates] concessum vel traditum fuit.

10. CDL III.2:11: ligna ad sales coquendas; alpecella que apellatur Pennice, ubi domna et genitrix nostra Theodelinda, gloriosissima regina, ob amore patris nostri Columbani ascendit ad locum istum previdendum.

11. CDL III.3:12-5 (Pavia, 17/07/625/6): quod vobis a Zussone [ . . . ] per donacione adque vindicione evenit.

12. See Polonio 1962, with older bibliography. 
Adaloald, a relationship established with the foundation of the monastery itself. This was the same family group that first attempted to make the royal office hereditary, and it is noteworthy that its members sought an element of continuity in their relationship with the monastery: all family members demonstrated a visible devotion to the house and its founder. It is important to underline, however, that the relationship with the royal court continued uninterrupted, even after the family's attempts to establish a dynasty were brought to an end with Adaloald's deposition in 626.

Indeed Arioald, the king who deposed Adaloald, played an important role in the monastery's history, even if he did not issue another diploma for Bobbio. He appears in the Vita Columbani with a double character. Initially he is presented with the typical negative traits of an Arian and a barbarian. Indeed, Jonas recounts that a monk of Bobbio, Blidulf, who had been sent to Pavia, was a victim of an ambush by one of Arioald's men, who at that time was still a duke. At Arioald's instigation, he had badly beaten the monk, but divine intervention restored him to good health and punished the assailant dreadfully, instilling in the duke at the same time a superstitious fear. ${ }^{13}$ This is a typical narrative within its genre, in which Arioald is presented as a barbaric subverter of the Catholic faith. According to the account, even the gifts the duke sent to the monastery were refused by Abbot Athala, because they came from an Arian.

In the preceding chapter, however, Jonas had relayed a different story, which despite its position in the text in fact refers to a period after the aggression shown toward Blidulf, since Arioald is already shown to be king. The bishop of Tortona, Probus, who wanted to extend his control over the monastery, had sought the support of other northern Italian bishops, and together with them he requested the king's intervention. The king, however, who was the same Arioald who had earlier had the monk Blidulf beaten, replied that he was unable to intervene in a matter that could only be resolved by a synod, stating that in any case he could not favor "those who wished to provoke harm against a servant of God." 14

In this case Arioald's behaviour is exemplary and very distant from that exhibited when he was duke. Taken together this shows that an association with a monastery like Bobbio was fundamental for the prestige of whoever held royal office, even if the sovereign was an Arian. Indeed, this was a relationship perhaps even more important than that with the bishops, which the Lombard kings also sought out, in a way comparable to their Frankish counterparts. Indeed

13. VC II.24: 286-9. On Jonas's Vita Columbani see Wood 1982: 63-80; O'Hara 2009: 126-53; O'Hara and Wood 2017.

14. VC II.23: 281-3. 
Arioald, in his struggle to establish himself on the throne against Adaloald, had been supported by a number of northern Italian bishops, which aroused the severe protests of Pope Honorius I, who in 625 had written to the exarch of Italy, Isacius, requesting that he take severe measures against those bishops. ${ }^{15}$ And yet the year after Honorius's letter, Arioald, as we have just seen, set himself against the very same bishops who had supported him, positioning himself in favour of Bobbio, even going so far as to assist, "with public support" (supplimento publico) Bertulf's mission to Pope Honorius in Rome (in which Jonas himself took part). ${ }^{16}$

The pope favored Bobbio and issued a bull in 628 that, placing the monastery under the jurisdiction of the Roman Church, proclaimed its exemption from any episcopal interference. The bull has survived-again as a copy-in a text that although far from correct is considered to be substantially authentic. ${ }^{17}$ It can be read as the pope's response to the position of the northern bishops and, at the same time, an expression of his attempt to establish good relations with the Lombard court. Bobbio, therefore, emerges as a pawn in the wider, complex game of Italian politics.

We can trace the history of relations between the monastery and the Lombard court relatively well thanks to a series of royal diplomas, which have been preserved or recorded in other later diplomas. Privileges were issued by Kings Rothar, Rodoald (who confirmed the monastery's exemption from episcopal jurisdiction, in a text the authenticity of which is not assured), Grimoald, Cunipert, Liutprand, Ratchis, Aistulf, and Desiderius. ${ }^{18}$ Out of all these sovereigns, the association with King Liutprand emerges as particularly important, as it was this king who commissioned the tombstone for Cumian, a monk of Irish origin who lived in Bobbio around the middle of the seventh century. The text of the epigraph inscribed on the tombstone requests that the saint intercede in favor of the king. ${ }^{19}$ There also exists a stone fragment, preserved in the museum of Bobbio, that may even suggest the king stayed in the monastery. ${ }^{20} \mathrm{He}$ would have been the first to have done so after King Adaloald, approximately a century earlier, a testimony to a deep and uninterrupted link between court and cloister.

15. Epistolae Langobardicae 2: 694.

16. VC II.23: 282.

17. CDSCB 10: 100-3. Even Pope Theodore's bull of 643 (CDSCB 13:104-12) is considered today to be substantially authentic: Anton 1975: 55-9; Piazza 1997: 13-4.

18. CDL III.5:18-21 (Rodoald, Pavia, 4/11/625); 22:108-11 (Ratchis, Carbonara al Ticino, 5/08/747); other kings' diplomas are mentioned in Ludovici II Diplomata 31: 127-32.

19. CDSCB 20:122: At pater egregie potens intercessor existe / pro gloriosissimo Liutprando rege qui tum/praetioso lapide tymbum decoravit devotus / sit ut manifestum almum ubi tegitur corpus.

20. CDSCB 31:135: “+: D: LIUTPRAND REXV.” 


\section{Lombard Italy and Columbanus's Legacy}

Liutprand himself, and Ratchis after him, had donated a number of revenues to the monastery deriving from a public curtis by Lake Garda, where even well into the ninth century the monastery had important possessions, including a church dedicated to Saint Columbanus. ${ }^{21}$ Amid this uniform picture of donations we also find a notice of a different kind. We learn from a diploma issued by Ratchis in 747 that during Liutprand's reign a part of the property donated by a certain Hilpranda was taken from the monastery. Ratchis, after he had had three of his silvani verify its boundaries, completely restored the land to the monastery. ${ }^{22}$ This was probably an instance of illegitimate occupation by local landowners, overturned by King Ratchis's intervention, and should certainly not be seen as evidence for any lack of support from Liutprand for the monastery. Such support, on the contrary, is amply demonstrated by the evidence presented above. Furthermore, the donor's name, Hilpranda, appears very rarely in the sources of the period and thus most likely belonged to a member of the same royal family as Liutprand and his nephew, Hildeprand, further strengthening their connection with Bobbio. ${ }^{23}$

All the donations made by the Lombard kings were later confirmed in a privilege issued by Louis II in 860, with the exception of those made by Rothar and Rodoald, the authenticity of which therefore remains in doubt. ${ }^{24}$ This diploma (which was confirmed in 877 by Carloman), together with the first great Adbreviato of the monastery's property (composed only two years later), represents the endpoint, from the point of view of its property, of the monastery's history in the Lombard and Carolingian era. ${ }^{25}$ Around thirty years previously, Wala had had an earlier register of the monastery's property drawn up, which indicated the essential outlines of its internal organization. ${ }^{26}$

It is not easy to go beyond these details, which with very few exceptions are almost entirely derived from Jonas's biography of Columbanus and the royal

21. Castagnetti 1979: 1: 137 (Adbreviatio de rebus omnibus Ebobiensi monasterio pertinente, 862), 2: 158 (Adbreviatio de rebus omnibus Ebobiensi monasterio pertinente, 863), 4: 180 (Breviarium de terra sancti Columbani, X-XI century). From the curtis were obtained cash and in-kind revenues, including the proceeds of a fishery. Noteworthy is also what is written in the Adbreviatio of 862 (1: 143): In Caniano [near Pavia] xenodochium sancti Martini, quod datum fuit per iudicatum sancto Columbano, spetialiter in suo thesaurario perenniter inibi pertinens; it is very likely that this iudicatum was of the Lombard period.

22. CDL III.22:110: Manifestum est, eo quod ante hos annos temp[ore praecellentissimi] domni Liutprandi regis vobis subtractum est in aliquod fine nostra Turi[o et alpe nostra Carebalo, quod] per Hilpranda [...] in suprascriptum cenubium relaxatum est.

23. See Jarnut 1973:145, which lists only the Hilpranda of Ratchis's diploma, and 147, where are listed some names (from Tuscany) in the masculine form Ilprandus-Ildiprandus.

24. Ludovici II Diplomata 31: 127-32 (Marengo, 7/10/860); Carloman's diploma (Cortenuova, 20/10/ 877): MGH, Diplomata Regum Germaniae ex stirpe Karolinorum, I.6: 292-4.

25. See footnote 21 for the two versions of the Adbreviatio.

26. CDSCB 36: 139-41. 
diplomas. For this reason, while we can grasp a basic picture of Bobbio's relationship with the Lombard kings, its connection with the Lombard elite remains completely obscure. This could simply be the result of the destruction of private documents belonging to the monastery. However, since Bobbio did not undergo any particular disasters (such as fire or demolition) over the course of its history that would explain the loss of the oldest part of its archive, perhaps another explanation ought to be looked for. Comparison with other Italian monasteries shows that elsewhere private documents have partially survived, have been cited explicitly in later royal diplomas, or were copied into the great cartularies of the twelfth century (as was the case for Santa Maria at Farfa and San Vincenzo al Volturno). For Bobbio, by contrast, other than the two documents concerning Zusso and Hilpranda's property that we have mentioned, our only surviving private charter is found in a half-erased text (probably from the eighth century), over which Ratchis's 747 diploma was written. ${ }^{27}$ The document must certainly have come from the monastery's archive. Furthermore, a guard-leaf from a Bobbio manuscript contains two notices that record the content of two documents, also attributable to the eighth century. ${ }^{28}$ Nevertheless, for a monastery directly linked to the royal court, this is a very small quantity of documents.

Nor is it very useful, although it has been attempted, to reconstruct the monastery's Lombard-era possessions on the basis of working backward from the Carolingian diplomas. This is not only because it is difficult to distinguish the Carolingian donations from those of an earlier period, but also because in any case-even if we assume that the Lombard "stratum" could be identified-one would not be able to distinguish between private and public donations. Also, the fact that in Abbot Wala's breve memorationis (dated to 833-835), the basic text for this type of reconstruction, Bobbio's property is organized into curtes, further suggests that its possessions were mostly of a public origin. Such an origin is probably all the more probable for those more distant possessions, such as the curtes in Tuscia, or indeed the property by Lake Garda, not to mention the land in the capital, Pavia (in these last two cases we are dealing with cellae rather than curtes). ${ }^{29}$

It should be concluded, therefore, that private donations made a weak contribution to the formation of Bobbio's patrimony. In order to explain this (at least partially), it is relevant to consider the date of the house's foundation in the very first years of the seventh century. This was more than a century earlier than the foundation (or re-foundation) of all the other great monasteries of Italy,

\footnotetext{
27. $C D S C B$ 28: 132.

28. $C D S C B$ 30: $134-5$.

29. See footnote 26 .
} 
including San Salvatore (later Santa Giulia) in Brescia, Novalesa, Nonantola, San Salvatore al monte Amiata, Farfa, San Vincenzo al Volturno, and Montecassino. This fact did not favor Bobbio, since during the seventh century the elites of the Lombard kingdom had not yet begun to make significant donations to monasteries, in contrast to what happened in the eighth century. Liutprand's legislation of 713 , which legalized and encouraged donations pro anima and particularly benefited monasteries, certainly sanctioned an already existing situation, although not one that can have been much older. ${ }^{30}$ We can state this with relative certainty because the preservation of Lombard private charters begins precisely at the beginning of the eighth century, increasing much more markedly only around the middle of that century. Clearly the conservation of these documents is owed to the fact that they contained donations to ecclesiastical institutions, which preserved them in their archives as a result. ${ }^{31}$ By contrast seventh-century charters, which certainly must have existed, have been lost, as they were barely if at all connected to ecclesiastical institutions.

Thus the preservation of documents and the influx of donations to churches (and monasteries above all) were two contemporaneous processes. Such donations therefore were a phenomenon foreign to the long, seventh-century history of Bobbio. When donations did begin to increase, Bobbio found itself faced with many rivals, cutting it off first of all from a potential range of donations from beyond the region, which instead went to local monasteries, very many of them family foundations. At the local level, Bobbio cannot have benefited from the more modest wealth of the kingdom's northwest elites, who are barely represented in the surviving charters of the Lombard period (and not only those pertaining to Bobbio). As for Emilia, the region was a frontier zone and remained disputed until the 730 . Furthermore, Bobbio suffered in particular from the foundation of San Salvatore in Brescia, which became the royal monastery par excellence and attracted donations not only from the sovereigns, but also from the Lombard elites of the entire Po valley. ${ }^{32}$ Bobbio's considerable patrimony, made visible by the polypytchs of the Carolingian era, was therefore fundamentally public in origin.

Bobbio's role within the history of the Lombard kingdom has traditionally been linked to three questions, which despite their interconnection, we consider separately here for greater clarity. The first problem concerns the Three Chapters heresy, its diffusion within the Lombard kingdom, and the schism associated with it after 606. It was then that the division took place between the

\footnotetext{
30. Liutprandi leges, 6: 140 .

31. On the importance of this transformation, La Rocca 1997: 31-54 and 1998: 77-87.

32. Gasparri 1978: 429-42.
} 
two seats of Aquileia and Grado. ${ }^{33}$ The former was in Lombard territory and adhered to the Three Chapters, while the latter was Catholic and in Byzantine territory.

In Italian historiography, the Three Chapters heresy has always been considered to be of great significance for the interpretation of the history of the Lombard kingdom. This became all the more true after the studies of Giampiero Bognetti, who wrote in the first half of the twentieth century. According to Bognetti, whose influence on Italian early medieval historiography has been (and to some degree continues to be) enormous, the whole history of the kingdom was characterized by a long combat between Arians (who were almost pagans) and Catholics. ${ }^{34}$ However, this is not an idea that current historiography accepts, because Arianism had no political role in Lombard Italy whatsoever; indeed, the traces it did leave are rather weak and disappeared rapidly. ${ }^{35}$ For Bognetti, by contrast, the struggle continued well into the eighth century. As part of this history, the Three Chapters controversy was important because it supposedly represented an opportunity for the Lombard sovereigns (Agilulf and Theodelinda, and their son Adaloald) to construct a kind of "national church," which was Catholic but, through its adhesion to the Three Chapters, hostile to Byzantium. The religious unity of their subjects, it is argued, greatly increased the Lombard kings' prestige and authority. ${ }^{36}$

Columbanus is located in this context, and he did indeed send one of his letters (the fifth) to Pope Boniface IV, urging him to assemble a council to resolve the schism. ${ }^{37}$ According to Bognetti's interpretation, and to very many others after him, it was necessary for the Lombard kings to isolate Rome from Byzantium, leading it to condemn the Fifth Council; in this way, the faith of the kingdom's Catholic subjects, who were faithful to Rome, would have been cemented, while at the same time definitively distancing them from Byzantium in religious matters. ${ }^{38}$

The number of anachronisms and unproven assumptions in Bognetti's writings are so great that it would take many pages to identify them all, a task I have already done elsewhere and thus do not repeat here. ${ }^{39}$ I remain here with the facts as they appear in the sources. ${ }^{40}$ Undoubtedly Agilulf and Theodelinda had

33. Paul the Deacon, Historia Langobardorum IV.33:127; Pohl 2007: 243-4.

34. Bognetti 1966 (first edition 1948).

35. Fanning 1981: 241-58; Pohl 2000: 47-58; Gasparri 2001: 219-53.

36. Referring to Agilulf, Columbanus wrote: dolor eius est schisma populi (Ep. 5.8: 44).

37. Ep. 5: 36-56; on Columbanus's epistulae see Wright 1997: 29-92; Leso 2013: 358-89 (with bibliography).

38. Bognetti 1966: $214-5$ and 283.

39. Gasparri 2003: 3-28.

40. On the Three Chapters in general, see Chazelle and Cubitt 2007; for Italy see Azzara 2007: 209-22. 


\section{Lombard Italy and Columbanus's Legacy}

an acute interest in seeing the condemnation of the Fifth Council. Columbanus says so clearly: his letter to the pope is written on Agilulf's command (iussio); the king's intervention had provoked in him stupor and sollicitudo, and for this reason he could not evade the task. Columbanus, although he professes himself to be a humble peregrinus, was nevertheless strong in faith-immune to any heresy and faithful to the Roman Church-something he had always demonstrated together with all of his people, the Iberi, "inhabitants of the extreme ends of the world," and for that reason he was able to speak to the pope as a faithful disciple. ${ }^{41}$ It remains an open question whether he knew in depth the content of the debates around the Three Chapters, but that is not particularly important, because in reality he is preoccupied with something else. This is above all a call for the unity of the church, necessary to combat its enemies: "Be vigilant, for the water is already entering the ship of the church, and the ship is in danger." 42

It is interesting how Columbanus's letter reveals his proximity to the two sovereigns and their son, who twice in the letter are presented-very effectivelyas profoundly involved in an attempt to overcome the division of the Christian people (the scisma populi) caused by the condemnation of the Three Chapters. And while Columbanus defines Agilulf as a rex gentilis, he simultaneously (with little logic) presents the same king, together with Theodelipdo as engaged in the struggle against the Arians: "And indeed the kings hatt a long time this Arian disgrace in this region, oppressing the Catholic faim; now they ask to strengthen our faith. ${ }^{43}$

It is possible that during his stay in Milan Columbanus came across Arian groups, against whom he directed his preaching, although there is nothing to prove that they were Lombards. Moreover, the character of the Lombard sovereigns appears contradictory in the eyes of the monk; ultimately he regards them as supporters of Catholicism, even if the king, Agilulf, had even recently come from an Arian background. However, no evidence allows us to deduce the existence of precisely defined religious "parties" in Lombard Italy, or indeed at court. Nor is it possible to identify Columbanus as a member of such a party. The simplest explanation is that the Irish abbot, strengthened by the purity of his faith, intervened at the urging of the king, who was willing to support his aspiration to build a monastery in Italy and strove to overcome the religious

41. Epp. 5.1: 37, 5.3: 38 .

42. Ep. 5.3: 38: Vigilate, quia aqua iam intravit in ecclesiae navem, et navis periclitatur.

43. Ep. V.17: 54: Reges namque Arrianam hanc labem in hac diu regione, calcando fidem caholicam, firmarunt; nunc nostram rogant roborari fidem. 
conflict that divided the population, the scisma populi. Attributing other roles to Columbanus, whether political or missionary, is not justified by the sources. ${ }^{44}$

The whole problem of Bobbio's relationship with the Three Chapters controversy demands one further reflection. Apart from Columbanus's letter, the affair is only mentioned in Bobbio's sources after the death of the house's founder in book II of Jonas's Vita Columbani, in a long but rather obscure episode ${ }^{45}$ It concerns a monk named Agrestius, who had entered the monastery of Luxeuil during the time of Abbot Eustasius. Agrestius, driven by a desire to carry out missionary activity, had gone first to the Bavarians (with no success) and later to the diocese of Aquileia, where he joined the supporters of the Three Chapters schism. Jonas writes that at this point Agrestius had a notary, Aureus, send an epistola venenosa on behalf of King Adaloald to Abbot Athala at Bobbio, which evidently called on him to join the schismatics. Both here and later on, Jonas ridicules Agrestius's positions. Agrestius, however, did not give in. He returned to Luxeuil and there "with the thorns of schism he tempted" Abbot Eustasius, who nevertheless resisted. Thanks to the involvement of a number of Burgundian bishops, Agrestius managed to have the king, Chlothar, assemble a synod at Mâçon (in 626 or 627), although he was defeated there. ${ }^{46}$

Notably the Council of Mâçon did not actually discuss the schism. Instead, it discussed a number of practices associated with Columbanian monasticism, which according to Agrestius went against canon law and thus were to be considered heretical. Also surprising is that the problem of how to calculate Easter was not mentioned as one of these malpractices. Apart from that, Jonas completely discards discussion of the schism, despite what he wrote at the beginning about contacts between Agrestius and Eustasius, when he had tempted the abbot about the schism.

The whole series of events mostly appears as an internal development within Columbanian monasticism, which at the Council of Mâçon-according to Jonas's account-wished to demonstrate its complete alignment with Rome and its positions. This is confirmed by Jonas's description of the journey to Rome taken by Bertulf (whom we have mentioned already). ${ }^{47} \mathrm{He}$ underlines that Honorius was above all concerned about the particular monastic practices of Bobbio's monks while, conversely, he was not at all concerned about their potential sympathy for the Three Chapters. According to Jonas, Honorius later

44. Leso 2010.

45. VC II 9: 246-51.

46. VC II 9: 248: Eusthasium scismatis aculeis temptat. See also Fischer and Wolfram, chapters 8 and 9 in this volume.

47. See text and n. 16 . 


\section{Lombard Italy and Columbanus's Legacy}

urged Bertulf to pursue the struggle against the Arian heresy. ${ }^{48}$ I maintain, however, that the pope's exhortation to continue fighting the "perfidy of the Arian pestilence" conforms to a topos of papal action rather than reflecting a real crisis on this front. Besides this, the only concrete measure taken by Honorious concerning heresy that we know about is the deposition of Fortunatus, the patriarch of Aquileia and a supporter of the Three Chapters, in favor of the Roman and Catholic Primigenius. ${ }^{49}$ We know of no actions taken against the Arians.

In conclusion, the sources are contradictory. When reading Jonas in particular, it should be remembered that he wrote first and foremost to demonstrate the purity of faith of the monks of Bobbio and their fidelity to Rome. The Arians and supporters of the Three Chapters assume their roles within this narrative scheme, in which, however, the true contest concerned the particular customs of Irish monasticism. With his account, Jonas sought to affirm that all such customs that went against Roman tradition had already been abandoned. There is not, however, a single case in which we can deduce the existence of a surge in missionary activity (whether against Arians, supporters of the Three Chapters, or pagans), neither generally in the Lombard kingdom nor specifically in the territory where Bobbio was established. Bognetti's old hypothesis about the missions carried out by eastern monks has been definitively overturned, and there is no reason to substitute an equally implausible theory that attributes an equivalent role to the monks of Bobbio. ${ }^{50}$

As a consequence, it is incorrect to imagine that, by supporting Columbanus and granting him the land (and the church of Saint Peter) where he built his monastery, Agilulf intended to use Bobbio as a vehicle for conversion. Bognetti and his disciples presented the hypothesis that Agilulf wished to employ the monks of Bobbio in combating the "Arian nationalism" of the most conservative Lombard warriors. ${ }^{51}$ These warriors supposedly lived in isolated military settlements (the famous-and equally fictional-arimanniae) ${ }^{52}$ positioned along the Apennines on the Byzantine frontier with Liguria, territory that was effectively under the control of the Byzantine Empire until 643. According to Bognetti, had these warriors converted to Catholicism, they would have become more tightly bound to the activities of the monarchy (by now Catholic), strengthening its authority. Again, however, there is no evidence for such

48. VC II 23: 282-3.

49. Epistolae Langobardicae 3: 694-6 (November or December 625).

50. See Gasparri 2001: 225-32. The theory of the missionary role of Bobbio is still present in Italian historiography; see, e.g., Polonio 1962: 91-4; Zironi 2004: 9-21.

51. See above, footnote 37 .

52. On the arimanniae, see Tabacco 1966; Jarnut 1971; Gasparri 1978; the first historian who interpreted the arimanniae as military settlements inside the kingdom was Bognetti 1938: 109-34. 
missionary activity from Bobbio. The monastery's dependencies (the age of which we cannot determine) show no trace of missionary activity.

In conclusion, it is not justifiable to attribute to Bobbio a missionary role that is simply not attested by the sources. The theory derives from the belief that the primary task of the Irish monks was the conversion of pagans and Arians, but this has been disproved by the work of Ian Wood, which has demonstrated that the monks' basic goal was to promote their model of Christian life. Missionary work was simply a consequence of activity that had other ends. ${ }^{53}$

Alongside the Three Chapters controversy, the idea of a missionary vocation has been the second big problem to have concerned students of Bobbio. However, there remains one other theme, the third question that I referred to earlier: the notion of the monastery's "strategic" - indeed military-role. In this view, Bobbio was "a sentry in a recently conquered area, looking above all towards Liguria, still entirely in Byzantine hands." 54 This theory-which not only derives from Bognetti and Italian historians but has been put forward by, for example, Karl Schmid - has not solely been applied to Bobbio. Indeed, the idea almost always emerges when the foundation of a royal monastery is discussed. We find it for Farfa, on the borders of Rome's territory; for Nonantola, close to the Exarchate; and for San Salvatore al Monte Amiata in Tuscany, a region that was still not well-controlled by the kings in Pavia. ${ }^{55}$ The sources say nothing at all about any of this. The Lombard monasteries never had a military function or a role in supervising frontiers or traffic intersections. Such an explanation for Bobbio fails to grasp the significance of its monastic settlement. Its relative proximity to roads, and its position between the Trebbia and Aveto valleys, enabled the monastery to intercept the flow of pilgrims on their way to Rome and thus to secure the provision and survival of the community. None of this was at all incompatible with the practice, typical of Irish monks, of choosing wild and remote locations for their foundations.

From the point of view of the king, the monastery, which developed under royal protection, undoubtedly projected a public presence in a particular territory. But in no way was it a strategic settlement in a military sense. This erroneous idea derives from an argument first put forward by Rudolf Schneider at the beginning of the twentieth century and later reprised and popularized-once again-by Bognetti. This view understood all Lombard settlement as linked to the military control of territory. ${ }^{56}$ Monasteries too were situated within this

\footnotetext{
53. Wood 2001.

54. Quotation from Polonio 1962: 15. See also Destefanis 2002: 91-5.

55. Schmid 1972: 1-36.

56. Schneider 1924.
} 


\section{Lombard Italy and Columbanus's Legacy}

wider, general, strategic framework - which of course never existed. Such a conception of Lombard settlement, understood to have been rigidly separated from that of the Roman population, has largely been refuted, although some of its consequences-including that of viewing monasteries as strategic settlementshave yet to become outdated. ${ }^{57}$

Bobbio then had no strategic or military role, nor was it a major center of missionary activity. Moreover, the modest level of paganism in the region's countryside would not have justified such a role, nor would the hypothetical, Lombard arimanniae. Conversely, Bobbio represented the first, experimental example of a royal monastery in Lombard Italy, in a way that expressed the new politics of the kingdom under Agilulf and Theodelinda. With the most difficult phase of settlement and conquest over, the Lombard monarchy in this way developed new and more mature methods of government and power, following models from Byzantium as well as the neighboring Frankish kingdom. Among such methods, patronage of monasteries was one of the most typical examples, together with the foundation of churches (such as San Giovanni in Monza) or rituals of royal inauguration inspired by the Hippodrome in Constantinople. ${ }^{58}$ Bobbio was thus the first example of a royal monastery, a model that was reprised with great success with San Salvatore of Brescia in the following century. ${ }^{59}$ At the same time, it inaugurated a new phase of evolution for the Lombard kingdom and the politics of its kings. By now stably in control of their territory, they sought a deeper legitimacy for their power through an association with ecclesiastical institutions and thus prefigured models of practice that would become standard during the course of the eighth century.

\section{BIBLIOGRAPHY}

Anton, H. H. (1975) Studien zu den Klösterprivilegien der Päpste im Frühen Mittelalter. Beiträge zur Geschichte und Quellenkunde des Mittelalters 4. Berlin and New York.

Azzara, C. (2007) Il regno longobardo in Italia e i Tre Capitoli. In C. Chazelle and C. Cubitt (eds.), The Crisis of the Oikoumene: The Three Chapters and the Failed Quest for Unity in the Sixth-Century Mediterranean. Turnhout, Brepols, 209-22.

Bognetti, G. P. (1938) “Arimannie e guariganghe." In Wirtschaft und Kultur: Festschrift zum 70. Geburtstag von A. Dopsch. Leipzig, R. M. Rohrer Verlag, 109-34.

Bognetti, G. P (1966) S. Maria foris portas e la storia religiosa dei Longobardi. Milan, Giuffrè.

Castagnetti, A. (1979) "S. Colombano di Bobbio." In A. Castagnetti, M. Luzzati, G. Pasquali, and A. Vasina, Inventari altomedievali di terre, coloni e redditi. Roma, Istituto storico italiano per il medio evo, 119-92.

57. Gasparri 2003: 3-28.

58. Paul the Deacon, Historia Langobardorum III 35: 114 and IV 21: 123-4.

59. Gasparri 1978: 436-40. 
Chazelle, C., and C. Cubitt (eds.) (2007) The Crisis of the Oikoumene: The Three Chapters and the Failed Quest for Unity in the Sixth-Century Mediterranean. Turnhout, Brepols.

Destefanis, E. (2002) Il monastero di Bobbio in età altomedievale. Firenze, All'insegna del giglio.

Diplomata Regum Germaniae ex stirpe Karolinorum (1934), ed. P. Kehr. MGH, Berlin, .

Epistole Langobardicae collectae (1892), ed. W. Gundlach. MGH, Epistolae III. Berlin.

Fanning, S. C. (1981) "Lombard Arianism Reconsidered." Speculum 56: 241-58.

Gasparri, S. (1978) "La questione degli arimanni." Bullettino dell'Istituto storico italiano per il Medio Evo e Archivio Muratoriano 87: 121-53.

Gasparri, S. (2001) "Roma e i Longobardi." In Roma nell'alto medioevo, I. Spoleto, Settimane di studio del Centro italiano di studi sull'alto medioevo, 48.

Gasparri, S. (2003) "I Germani immaginari e la realtà del regno: Cinquant’anni di studi sui Longobardi." In I Longobardi dei ducati di Spoleto e Benevento, I. Spoleto, Atti del XVI Congresso internazionale di studi sull'alto medioevo, 3-28.

Jarnut, J. (1971) "Beobachtungen zu den langobardischen Arimanni und Exercitales." Zeitschrift für Rechtsgeschichte: Germanische Abteilung 88: 1-28.

Jarnut, J. (1973) Prosopographische und sozialgeschichtliche Studien zum Langobardenreich in Italien (568-774). Bonn, L. Röhrscheid Verlag.

La Rocca, C. (1997) 'Segni di distinzione: Dai corredi funerari alle donazioni 'post obitum' nel regno longobardo." In L. Paroli (ed.), L'Italia centro-settentrionale in età longobarda. Firenze, All'insegna del giglio, 31-54.

La Rocca, C. (1998) "Donare, distribuire, spezzare: Pratiche di conservazione della memoria e dello status in Italia tra VIII e IX secolo." In G. P. Brogiolo and G. Wataghin (eds.), Sepolture tra IV e VIII secolo. Padua, SAP, Società archeologica padana, 77-87.

Leso, T. (2010) "Iona hebraice, Peristera graece, Columba latine: Per un riesame critico delle fonti sullesprienza colombaniana tra VI e VII secolo Francia e Italia." MPhil dissertation, Università degli Studi di Padova.

Leso, T. (2013) "Columbanus in Europe: The Evidence from the Epistulae." Early Medieval Europe 21.4: 358-89.

Liuprandi Leges = Le leggi dei Longobardi: Storia, memorie e diritto di un popolo germanico (2005), ed. C. Azzara and S. Gasparri. Rome, Viella.

Ludovici II Diplomata (1994), ed. K. Wanner. Fonti per la storia dell'Italia medievale, Antiquitates 3. Rome, Istituto storico italiano per il medio evo.

O' Hara, A. (2009) “The Vita Columbani in Merovingian Gaul." Early Medieval Europe 17.2: $126-53$.

O' Hara, A. and I. Wood (eds.) (2017) Jonas of Bobbio: Life of Columbanus, Life of John of Réomé, and Life of Vedast. Translated Texts for Historians 64. Liverpool, Liverpool University Press.

Paul the Deacon (1878) Historia Langobardorum = Pauli Diaconi Historia Langobardorum. In G. Waitz (ed.), Scriptores rerum Langobardicarum et Italicarum saec. VI-IX. MGH. Hanover, $12-178$.

Piazza, A. (1997) Monastero e vescovado di Bobbio (dalla fine del X agli inizi del XIII secolo). Spoleto, Centro italiano di studi sullalto medioevo.

Pohl, W. (2000) "Deliberate Ambiguity: The Lombards and Christianity." In G. Armstrong and I. N. Wood (eds.), Christianizing Peoples and Converting Individuals. Tourhout, Brepols, 47-58.

Pohl, W. (2007) "Heresy in Secundus and Paul the Deacon." In C. Chazelle and C. Cubitt (eds.), The Crisis of the Oikoumene: The Three Chapters and the Failed Quest for Unity in the Sixth-Century Mediterranean. Turnhout, Brepols, 243-64. 


\section{Lombard Italy and Columbanus's Legacy}

Polonio, V. (1962) Il monastero di San Colombano di Bobbio dalla fondazione alletà carolingia. Genoa, Palatio archiepiscopali Ianuensi.

Prosperi continuatio Hauniensis (1922), ed. R. Cessi. Archivio Muratoriano 22. 629-41.

Richter, M. (2008) Bobbio in the Early Middle Ages: The Abiding Legacy of Columbanus. Dublin, Four Courts Press.

Schmid, K. (1972) "Zur Ablösung der Langobardenherrschaft in Italien durch die Franken." Quellen und Forschungen aus Italienischen Archiven und Bibliotheken 52: 1-36.

Schneider, F. (1924) Die Entstehung von Burg und Landgemeinde in Italien. Berlin, W. Rothschild.

Tabacco, G. (1966) I liberi del re nell'Italia carolingia e postcarolingia. Spoleto Centro italiano di studi sullalto medioevo.

Wood, I. N. (1982) “The Vita Columbani and Merovingian Hagiography." Peritia 1: 63-80.

Wood, I. N. (2001) The Missionary Life: Saints and the Evangelisation of Europe. Harlow, Routledge.

Wright, N. (1997) “Columbanus's Epistulae." In M. Lapidge (ed.), Columbanus: Studies on the Latin Writings. Woodbridge, Boydell Press, 29-92.

Zironi, A. (2004). Il monastero longobardo di Bobbio: Crocevia di uomini, manoscritti, culture. Spoleto, Centro italiano di studi sull'alto medioevo. 